\title{
Genetic Improvement of Rice (Oryza sativa) For Salt Tolerance: A Review
}

\author{
Oumarou Souleymane ${ }^{1}$, Massaoudou Hamidou ${ }^{1}$, Mahamadou Salifou $^{1}$, Baboucarr Manneh ${ }^{2}$, \\ Eric Danquah $^{3}$, Kwadwo Ofori ${ }^{3}$, \\ ${ }^{1}$ National Institute for Agronomic Research of Niger (INRAN), Niger \\ ${ }^{2}$ Africa Rice center (ex-WARDA)/AfricaRice Sahel Station B.P. 96 Saint Louis/Senegal \\ ${ }^{3}$ School of Agriculture, College of Basic and Applied Sciences, University of Ghana.
}

*Corresponding Author: Souleymane Oumarou, National Institute for Agronomic Research of Niger, Niger Email: umarsou@gmail.com

\begin{abstract}
Rice is one of the most important crops in the world. Salinity is a major problem limiting rice production in West Africa and the most serious abiotic constraint in Niger. It causes drastic yield losses and hence loss of income for rice farmers. Improvement of salt stress tolerance in rice varieties would increase grain yield of rice under slight salt-stress condition, and may also extend rice growing to regions with moderate salt content in soils. Many studies have been conducted in salt affected soils and rice genetic improvement in such hostile environment. The objective of this study was to provide a mini-review in genetic improvement of rice for salt tolerance under the following sections (1) characteristics of salt affected soils (2) scope of salt problem and the effect on plant growth (3) actors affecting salt tolerance of rice (4) screening methodologies for salt tolerance in rice (5) genetics of salt tolerance in rice (6) breeding methodology for tolerance to salinity in rice.
\end{abstract}

Keywords: Rice, salt tolerance, genetic, improvement

\section{INTRODUCTION}

Rice (Oryza sativa L.) has been cultivated as a major crop for over 10,000 years, and it sustains nearly one-half of the world population (Joseph et al., 2010). Rice is the third most cultivated cereal after millet and sorghum in Niger. Three major types of rice cultivation occur in Niger, namely i) traditional rice growing under flooding in the Niger River edge and pond; ii) Small private rice growing; and iii) rice growing on irrigated perimeter with total control of water.

Rice production in Niger is limited by factors such as low soil fertility, weeds, diseases, extreme temperatures and salinity (Sido, 2010). Salinity is a major problem limiting rice production in West Africa, particularly within the Sahel where rainfed rice production is not feasible (Manneh et al., 2007). It is the most serious abiotic constraint of rice production in Niger. Up to $20 \%$ of irrigated fields are affected by salt problems (Guero, 2000). Maas and Grattan (1999) have estimated that rice yields decrease by $12 \%$ for every unit $\left(\mathrm{dSm}^{-1}\right)$ increase in EC above $3 \mathrm{dSm}^{-1}$. This accounts for drastic yield losses and hence loss of income for rice farmers (Gregorio et al., 2002; El-Bably, 2002). Improvement of salt stress tolerance in rice varieties would increase grain yield of rice under slight salt-stress condition, and may also extend rice growing to regions with moderate salt content in soils (Ming-Zhe et al., 2005).

The objective of this study was to do an overview of research on rice genetic improvement for salt tolerance.

\section{Taxonomy, origin, biology and ecology of rice}

Chang (1976) classified rice as follows

ORDER: Poales

FAMILY: Gramineae 
TRIBE: Oryzeae

GENUS: Oryza

SPECIES:

$$
\begin{aligned}
& \Rightarrow \text { Oryza glaberrima } \\
& \Rightarrow \text { Oryza sativa }
\end{aligned}
$$

There are 22 wild species of genus Oryza. Nine of the wild species are tetraploid. The remaining wild species and the two cultivated are diploid (Vaughan, 1994; Subudhi et al., 2006). O. sativa is the most widely grown of the two cultivated species. O. glaberrima however, is grown solely in West African countries (Linares, 2002). It can be distinguished from Oryza sativa because of its short, roundish, tough ligules and the small number of secondary branches on its panicles (Morishima, 1984). $O$. sativa has a relatively small (430 million base pairs) diploid genome $(2 \mathrm{n}=24)$. This is the smallest genome of all crops and approximately $50 \%$ of the genome is composed of repetitive sequences (Chang, 2003).

The common rice, Oryza sativa, and the African rice Oryza glaberima, are thought to be examples of parallel evolution in crop plants (Khush, 1997). Asian rice (Oryza sativa L.) was domesticated around 10,000 years ago from the wild annual $O$. rufipogon. It includes two main subspecies: indica (adapted to tropical and subtropical floating, lowland and irrigated agrosystems) and japonica (adapted to temperate and tropical upland ecosystems) (Chang, 1984; Khush, 1997). In a parallel evolution path, $O$. glaberrima was domesticated from annual $O$. breviligulata, which in turn evolved from perennial O. longistaminata (Khush, 1997).

The rice plant is an annual grass with round, hollow, jointed culms, flat leaves, and a terminal panicle. It is the only cultivated cereal plant adapted to growing in both flooded and non-flooded soils. Rice is grown under a wide range of climatic and geographical conditions on all five continents (Toriyama et al., 2005). Rice is grown in widely diverse production environments. Five major rice growing environments can be broadly identified based on water regime: irrigated, rainfed lowland, tidal wetland, deepwater, and upland (Khush, 1984).

\section{Characteristics of salt affected soils}

Salinity refers to the increase in the soil surface of dissolved salts, mostly sodium chloride or common table salt, but calcium, magnesium, sulphates and bicarbonates are also implicated in soil contamination by salts (Mba et al., 2007). A distinction can be made between primary salinization that involves salt accumulation through natural processes and secondary salinization processes caused by human interventions such as inappropriate irrigation practices (Gergely, 2012). There are two main categories of salt affected lands, the saline and sodic (alkali). This classification is based on the electrical conductivity (EC); soil $\mathrm{pH}$; and exchangeable sodium percentage or sodium adsorption ratio (SAR) (Lamond and Whitney, 1992; Flowers and Flowers, 2005).

Saline soils are dominated by neutral soluble salts consisting of chlorides and sulphates of sodium, calcium and magnesium. The $\mathrm{pH}$ of saturated soil paste is less than 8.2 and an electrical conductivity (EC) of the saturated soil extract of more than $4 \mathrm{dS} \mathrm{m}^{-1}$ at $25^{\circ} \mathrm{C}$. Sodium is generally the dominant soluble cation and the soil solution also contains appreciable quantities of divalent cations. In the presence of excess neutral soluble salts the clay fraction is flocculated and the soils have a stable structure. The permeability of soils to water and air and other physical characteristics are generally comparable to normal soils (FAO, 1988). Saline soils tend to dominate in arid and semi-arid regions.

Sodic soils tend to dominate in semi-arid and sub-humid regions. These soils contain sodium salts capable of alkaline hydrolysis, mainly $\mathrm{Na}_{2} \mathrm{CO}_{3}$. The $\mathrm{pH}$ of the saturated soil paste is more than 8.2. The exchangeable sodium percentage (ESP) is about 15 or more. The electrical conductivity of the saturated soil extract is generally less than $4 \mathrm{dSm}^{-1}$ at $25^{\circ} \mathrm{C}$. Sodium is the dominant soluble cation and High $\mathrm{pH}$ of the soils results in precipitation of soluble $\mathrm{Ca}$ and $\mathrm{Mg}$ such that their concentration in the soil solution is very low (FAO, 1988). High sodium concentrations in soil generally cause soil dispersion. The later causes soil pore blockage resulting in the reduction of soil permeability (Frenkel et al., 1978; Van De Graaff and Patterson, 2001; Pearson, 2004; Allotey et al., 2008). 


\section{Scope of salt problem and the effect on plant growth}

Oldeman et al. (1991) had estimated that 19.5 percent of irrigated land was salt-affected soils and that 2.1 percent of dryland agriculture, was salt-affected soils. The estimate of Flowers (2004) puts the figure of salt polluted soils at $900 \times 106 \mathrm{ha}$. All estimates indicate a disturbing trend for this major constraint to irrigated and dry land agriculture.

Most crops are adversely affected by salinity. In general, cereals are more tolerant than legumes (Reynolds et al., 2005). Many wild relatives of crop plants show greater tolerance than their domesticated descendents (Blum, 2004). Salt has both osmotic and salt-specific effects on plants, (Munns, 2002; Munns, 2005 ), impacting at different times (Shannon, 1997). Rapid changes can occur in field salinity (Richards, 1984). The effects of these changes are increased by plants preferentially extracting water from less saline areas of the root zone, by drought in rainfed environments (Srivastava and Jana, 1984), and by water logging in irrigated environments. This can be compounded by additional stresses which vary with time (Gregorio et al., 2003). Among cereals, rice (Oryza sativa) is the most sensitive (Munns and Tester, 2008).

The general effect of salinity is to reduce the growth rate resulting in smaller leaves, shorter stature, and sometimes fewer leaves (Munns and Termaat, 1987; Jacoby, 1994). Rajendran et al (2009) reported that salinity stress affects crop growth, yield and productivity. The reduction in shoot growth occurs in two phases: a rapid response to the increase in external osmotic pressure, and a slower response due to the accumulation of $\mathrm{Na}^{+}$in leaves (Munns and Tester, 2008).

Roots are also reduced in length and mass but may become thinner or thicker. Maturity rate may be delayed or advanced depending on species (Shannon and Grieve, 1999). Salinity effects on plants are complex (Greenway and Munns, 1980). The initial and primary effect of salinity, especially at moderate salinity concentrations, is due to its osmotic effects (Munns and Termaat, 1986). At the whole plant level, ion concentrations in plant tissues increase as a result of salinity stress. The measurable or visible effects of salinity on plants can include reduced growth rate, damage of meristems in growing shoots, reductions in yield components, or typical symptoms of nutritional disorders under osmotic and ionic stress. Grain yield reduction of rice under stress of root zone salinity can be caused by injuries at both seedling and maturity stages. In most commonly cultivated rice cultivars, young seedlings were very sensitive to root zone salinity (Zeng and Shannon, 2000).

The degree to which growth is reduced by salinity differs greatly with species and to a lesser extent with varieties within a species. The severity of salinity response is also mediated by environmental interactions such as relative humidity, temperature, radiation and air pollution (Shannon et al., 1994).

Salt affected soil can be improved using many techniques. These are: physical and hydro-technical amelioration, biological amelioration, and chemical amelioration (FAO, 1988).

\section{Factors affecting salt tolerance of rice}

Temperature and relative humidity are the most important climatic factors affecting salt tolerance (Singh et al., 2005). Many agronomic factors besides genetic potential affect the salt tolerance of plants. These include water regime, water quality, fertility level, land leveling, sowing/transplanting methods, crop rotation and ontogenic drift (Maas and Hoffman, 1977). Thus rice sensitivity to salt stress varies with plant growth stage (Makihara et al., 1999; Rao et al., 2008; Singh et al., 2010b).

Soil texture and structure greatly affect the expression of plant traits. A genotype can behave differently with its inherent salt tolerance in different soil textural classes at a particular stress level. Heavy clay soils impose more stress on a plant than sandy soils (Singh et al., 2010b).

\section{Screening methodologies for salt tolerance in rice}

Several methods were used for rice screening. These are:

Field screening: It is the most ideal method for identifying adapted and tolerant genotypes because salt tolerance is a complex phenomenon. However, spatial variability (Singh et al., 2010a) and Rapid changes (Richards, 1984) in the field makes escape possible. Hence, field screening becomes less reliable (Singh et al., 2010a) because of stress heterogeneity, the presence of other soil-related stresses and the significant influence of climatic factors (Xie et al., 2001; Gregorio et al., 2002). 
Screening in microplots: This method is used to screen mostly early segregating populations and also stabilized populations in addition to genetic studies (Singh et al., 2010a).

Salinity screening in solution culture: The solution culture technique is used in two ways: first, for screening up to seedling stage; second, for screening up to maturity.

Screening in trays: This method is employed for large-scale screening of varieties at germination/seedling stage (Singh et al., 2010a).

Screening in pots: For more precise studies of individual plant response under constant stress, round porcelain or plastic pots of 20-30 cm diameter, with a capacity of 4 or $16 \mathrm{~kg}$ soil and a provision to allow or prevent leaching from the bottom portion, are used. Genetic and physiological studies on salt tolerance that require precision are mostly done in pots (Singh et al., 2010a).

\section{Genetics of salt tolerance in rice}

The first reports on inheritance of salt tolerance came from Akbar and Yabuno (1972; 1975) in which it was inferred that inheritance of panicle sterility under salinity stress is controlled by a small number of dominant genes, but their studies were not extended to later segregating generations. Akbar and Yabuno (1977) reported that rice sterility in saline conditions, is determined by at least three genes. Most inheritance studies indicated a normal distribution of the trait in different populations, indicating its polygenic inheritance. Moeljopawiro and Ikehashi (1981) did one of the earliest studies in rice using two crosses between two moderately tolerant parents and between two tolerant parents rather than the contrasting parents. They found a low genetic response to selection and a high degree of environmental fluctuations. Shannon (1985) suggested that there is evidence of a genetically complex trait, showing heterosis, dominance and additive effects. In diallel analysis the effects of salinity on the seedling stage and on sterility suggested both additive and dominance effects, some with high heritability (Moeljopawiro and Ikehashi, 1981; Akbar et al., 1985). Another inheritance study for salinity tolerance in rice by Mishra et al. (1998) also inferred polygenic inheritance. It was also inferred that the salinity tolerance trait also lacked maternal influence. A similar inheritance study for sodicity tolerance was conducted involving the same populations. Results indicated that sodicity tolerance is also a polygenic trait acting both additively and with interactions between the alleles at some loci (Singh et al., 2001).

According to Lin et al. (2004) and $\mathrm{Hu}$ et al. (2012), salt tolerance of rice is the genetics of quantitative characters, which is controlled by multiple genes, with the additive and dominant effects, the former playing a major role (Moeljopawiro and Ikehashi, 1981; Gregorio and Senadhira, 1993; Gu et al., 1999). Akbar et al. (1985) reported that the dry matter weight of rice seedling under salt stress was affected by at least two groups of genes with additive effect, and no epistatic effect was detected. Thi Lang et al. (2010) reported that a dominant gene controls resistance to salt stress in the allelism test. Gregorio and Senadhira (1993) observed that there were two groups of genes involved in the sodium and potassium uptake in rice, one group for sodium exclusion and the other for potassium absorption.

\section{Breeding Methodology for tolerance to salinity in rice}

\section{$\checkmark$ Conventional Approaches}

These approaches include: mass selection, pureline selection, pedigree, bulk pedigree, modified bulk pedigree, shuttle breeding and backcross methods.

Mass selection method selects and bulks a few hundred to a few thousand superior plants on the basis of phenotype. It is used to improve old local varieties or purify existing varieties. Varieties are maintained through mass selection. Only those varieties that show genetic variation can be improved through mass selection (IRRI, 2007).

Pureline is the progeny of a single, homozygous, self pollinated plant. With pureline selection method you select a large number of plants whose individual progenies are tested. The best progeny is then released as a variety. It is used to develop a variety from local selections, introductions and old pureline varieties (IRRI, 2007).

The pedigree method has been the most widely used and successful in rice improvement. The method requires much time to periodically evaluate lines throughout the growing season and to keep records 
on which selection at maturity is based (Jennings et al., 1979).This is a classical method in which the lineage of the plant selection in the segregating generation is maintained until it is stabilized in the F7 or F8 generation. But, due to cumbersome procedures and the involvement of more resources, breeders are modifying this method and not adhering to it strictly (Singh et al., 2010b).

The bulk pedigree method seems particularly suitable to breeding for resistance to abiotic stresses (Grando and Ceccarelli, 2009). It has also proved to be ideal for use in participatory breeding programmes with self-pollinated crops (Ceccarelli and Grando, 2007). After producing the F1 and the F2 on station, three years of multi-location yield testing and selection of the bulks are carried out in the target environment(s). Selection is done between bulks by identifying the best populations for either yield or other characters. In parallel with the field testing of the bulks, a within-bulks selection is conducted only in those bulks that are selected for ext level of field testing. The families deriving from the populations that maintained their superiority for three cropping seasons will enter yield testing (Grando and Ceccarelli, 2009).

The modified bulk pedigree method is combination of pedigree and bulk breeding methods; this is almost as effective as the pedigree method, with relatively less use of resources. It has flexibility and is useful for less heritable traits, with the individual F2 plants harvested in bulk up to the F4 or F5 generations, followed by panicle selection and handling of the population as in the pedigree method. However, for highly heritable traits, the individual plants are selected in the earlier generations (F2 or F3), followed by bulking for a few generations and ultimately single-plant or panicle selection in the F5 or F6 generation (Singh et al., 2010b).

In the shuttle breeding approach, pre-breeding or advanced breeding materials are evaluated at different locations for their adaptability and the best adapted materials are again crossed and evaluated at different target sites in replicated trials. The latter step functions like the multi-location testing of advanced breeding materials (Mishra, 1994; Singh et al., 2010b).

In the backcross method the F1 generation and the progenies in the subsequent generations are repeatedly backcrossed to one of the original parents used in the cross. The objective of backcrosses method is to improve one or two specific defects of a high yielding variety. The backcross method has not been used extensively because of a lack of suitable recurrent parents (Khush, 1978).

\section{$\checkmark$ Non-conventional Approaches}

F1 anther culture has the twin advantages of increasing speed and improving breeding efficiency. Thus, it has become an effective tool to attain homozygosity of recombinants within the shortest possible time (Singh et al., 2010b). Following a conventional cross, it takes a minimum of four to five years before complete or $100 \%$ homozygosity is reached, as only two generations can usually be advanced in a single year. The use of anther culture overcomes this problem by regenerating F1 pollen into homozygous plants (Singh et al., 1992; Singh and Mishra, 1995).

The development of gene identification technologies using the tools of biotechnology provides ample opportunities for scientists to further improve modern cultivars (Jena and Mackill, 2008). Genomics tools and approaches, particularly the QTL mapping and comparative mapping offer new possibilities for crop improvement (Paterson, 2012; Saito et al., 2012). Significant progress in rice functional genomics is being made since the completion of the international rice genome sequencing project (Chen et al., 2011) which offers tremendous opportunities for breeders to improve this important crop by molecular breeding. Many molecular and genetic analyses have been performed on rice different traits such as: heading date (Izawa et al., 2003; Izawa, 2007; Shibaya et al., 2011), spikelet sterility (Ikehashi and Araki, 1986; Sawamura and Sano, 1996; Zhang and Lu, 1996; Wan et al., 1998; Wang et al., 1998; Yan et al., 2000; Ji et al., 2005; Zhao et al., 2006; Zhang et al., 2011), leaf size (Li et al., 1998; Shen et al., 2003; Kobayashi et al., 2006; Yue et al., 2006; Tong et al., 2007; Farooq et al., 2010) and yield components traits (Li et al., 1998; Erik et al., 2002; Ishimaru, 2003; Thomson et al., 2003; Yoon et al., 2006).

A major QTL (Saltol) derived from the salt-tolerant cultivar Pokkali has been located on chromosome 1. This QTL confers salinity tolerance at the vegetative stage and explains 64 to $80 \%$ of the phenotypic variance (Bonilla et al., 2002); it has also been detected in other varieties (Takehisa et al., 2004). A gene for salt tolerance at the vegetative stage has been identified in a similar position in the cultivar Nona Bokra and positionally cloned (Ren et al., 2005). 
Markers associated with tolerance for a variety of environmental stresses rank as important targets for molecular MAS in cereal breeding because these complex traits are often prohibitively difficult to screen using classical selection techniques. Efforts to identify QTL associated with tolerance to drought, salt and mineral deficiencies or toxicities (Champoux et al., 1995; Flowers et al., 2000; Gregorio, 2002; Kamoshita et al., 2002; Nguyen et al., 2002; Price et al., 2002) in a number of genetic backgrounds represent an important first step towards achieving this goal. Additional studies have specifically addressed the problems associated with G x G and G x E (Hittalmani et al., 1995; Zheng et al., 2000; Hittalmani et al., 2003; Li et al., 2003). In the area of biotic stress, several genes have been cloned and characterized for resistance to major diseases such as bacterial blight and blast (Song et al., 1995; Yoshimura et al., 1998; Bryan et al., 2000; Sun et al., 2004) and many other genes for disease resistance have been tagged with linked markers (Valent et al., 2001).

\section{CONCLuSiON}

There are 24 species of rice including 22 wild species and two (2) cultivated (O. sativa and $\mathrm{O}$. glaberrima). Rice is grown in widely diverse production environments: irrigated, rainfed lowland, tidal wetland, deepwater, and upland. Rice production is being constrained by salt problem. There are two main categories of salt affected lands, the saline and sodic (alkali). This classification is based on the electrical conductivity (EC); soil $\mathrm{pH}$; and exchangeable sodium percentage or sodium adsorption ratio (SAR). It is estimated that 19.5 percent of irrigated land was salt-affected soils and that 2.1 percent of dryland agriculture, was salt-affected soils.

Several methods were used for rice screening including; field screening, screening in microplots, screening in solution culture, screening in trays and screening in Pots. Many breeding methodologies are also employed to improved rice tolerance under salinity conditions. These include conventional and non conventional techniques.

Salt tolerance of rice is the genetics of quantitative characters, which is controlled by multiple genes, with the additive and dominant effects.

\section{REFERENCES}

Akbar, M., Khush, G. S. \& Hille Ris Lambers, D. (1985). Genetics of salt tolerance in rice. In: Proceedings of the international rice genetics symposium. IRRI, manila, Philippines. 399-409.

Akbar, M. \& Yabuno, T. (1972). Breeding for saline resistant varieties of rice. I. Variability for salt tolerance among some rice varieties. Jpn J Breed, 22: 277-284.

Akbar, M. \& Yabuno, T. (1975). Breeding for saline resistant varieties of rice. Iii. Response of f1 hybrids to salinity in reciprocal crosses between jhona 349 and magnolia. Jpn J Breed, 25: 215220.

Akbar, M. \& Yabuno, T. (1977). Breeding for saline resistant varieties of rice. Iv. Inheritance of delayed type panicle sterility induced by salinity. Japanese Journal of Breeding, 27: 237-240.

Allotey, D. F. K., Asiamah, R. D., Dedzoe, C. D. \& Nyamekye, A. L. (2008). Physico-chemical properties of three salt-affected soils in the lower volta basin and management strategies for their sustainable utilization. West African Journal of Applied Ecology, 12: 14.

Blum, A. (2004). The physiological foundation of crop breeding for stress environments. In proc. World rice research conf., Tsukuba, Japan, November 2004, pp. 456-458. Manila, the Philippines: International rice research institute.

Bonilla, P., Dvorak, J., Mackill, D. J., Deal, K. \& Gregorio, G. (2002). Rflp and sslp mapping of salinity tolerance genes in chromosome 1 of rice (oryza sativa 1.) using recombinant inbred lines. Philipp. Agric. Sci, 85: 68-76.

Bryan, G. T., Wu, K. S., Farrall, L., Jia, Y., Hershey, H. P., Mcadams, S. A., Faulk, K. N., Donaldson, G. K., Tarchini, R. \& Valent, B. (2000). A single amino acid difference distinguishes resistant and susceptible alleles of the rice blast resistance gene pi-ta. The Plant Cell, 12: 2033-2046.

Ceccarelli, S. \& Grando, S. (2007). Decentralized-participatory plant breeding: An example of demand driven research. Euphytica, 155: 349-360.

Champoux, M. C., Sarkarung, G. W. S., Mackill, D. J., O’toole, J. C., Huang, N. \& Mccouch, S. R. (1995). Locating genes associated with root morphology and drought avoidance via linkage to molecular markers. Theor. Appl. Genet, 90: 969-981. 
Chang, T. T. (1976). The origin, evolution, cultivation, dissemination and diversification of asian and african rices. Euphytica, 25: 425-441.

Chang, T. T. (1984). Conservation of rice genetic resources: Luxury or necessity? Science, 224: 251256.

Chang, T. T. (2003). Origin, domestication, and diversification. In: Smith, W. C. \& Dilday, R. H. (eds.) Rice. Origin, history, technology and production. Hoboken, New Jersey: John Willey and sons.

Chen, H., He, H., Zou, Y., Chen, W., Yu, R., Liu, X., Yang, Y., Gao, Y. M., Xu, J. L., Fan, L. M., Li, Y., Li, Z. K. \& Deng, X. W. (2011). Development and application of a set of breeder-friendly SNP markers for genetic analyses and molecular breeding of rice (oryza sativa 1.). Theor Appl Genet, 11: 633-644.

El-Bably, A. Z. ( 2002). Advanced and integrated approaches for crop tolerance to poor quality irrigation water in egypt. In: Zdruli, P., Steduto, P. \& Kapur, S. (eds.) Seventh international meeting on soils with mediterranean type of climate. Valenzano: Bari : CIHEAM-IAMB.

Erik, H. M., Yang, J. C., Stella, H., Peter, H. \& Peng, S. B. (2002). Are there associations between grain-filling rate and photosynthesis in the flag leaves of field-grown rice? J Exp Bot: 22172224.

FAO (1988). Salt-affected soils and their management. FAO Soils Bull, 39: FAO, Rome, Italy. 131.

Farooq, M., Tagle, A. G., Santos, R. E., Ebron, L. A., Fujita, D. \& Kobayashi, N. (2010). Quantitative trait loci mapping for leaf length and leaf width in rice cv. Ir64 derived lines. J Integr Plant Biol, 52: 578-584.

Flowers, T. J. (2004). Improving crop salt tolerance. J. Exp. Bot., 55: 307-319.

Flowers, T. J. \& Flowers, S. A. (2005). Why does salinity pose such a difficult problem for plant breeders? Agricultural Water Management, 78: 15-24.

Flowers, T. J., Koyama, M. L., Flowers, S. A., Sudhakar, C., Singh, K. P. \& Yeo, A. R. (2000). QTL: Their place in engineering tolerance of rice to salinity. J. Exp. Bot, 51: 99-106.

Frenkel, H., Goertzen, J. O. \& Rhoades, J. D. (1978). Effects of clay type and content, exchangeable sodium percentage and electrolyte concentration on clay dispersion and soil conductivity. Soil Sci. Soc. Am, J, 142: 32-39.

Gergely, T. (2012). Soil salinisation [Online]. European Commission - Joint Research Centre http://eusoils.jrc.ec.europa.eu/library/themes/salinization/. [Accessed 05/02 2014].

Grando, S. \& Ceccarelli, S. (2009). Breeding for quantitative variables part 3: Breeding for resistance to abiotic stresses. In: Ceccarelli, S., Guimarães, E. P. \& Weltzien, E. (eds.) Plant breeding and farmer participation. Rome: FOOD AND AGRICULTURE ORGANIZATION OF THE UNITED NATIONS.

Greenway, H. \& Munns, R. (1980). Mechanisms of salt tolerance in non-halophytes. Annu. Rev. Plant Physiol., 31: 149-190.

Gregorio, G. B. (2002). Progress in breeding for trace minerals in staple crops. J. Nutr, 132: 500S$502 \mathrm{~S}$.

Gregorio, G. B. \& Senadhira, D. (1993). Genetic analysis of salinity tolerance in rice (o. Sativa 1.). Theoretical and Applied Genetics, 86: 333-338.

Gregorio, G. B., Senadhira, D., Mendoza, R. D., Manigbas, N. L., Roxas, J. P. \& Guerta, C. Q. (2002). Progress in breeding for salinity tolerance and associated abiotic stresses in rice. Field. Crop. Res., 76: 91-101.

Gregorio, G. B., Senadhira, D., Mendoza, R. D., Manigbas, N. L., Roxas, J. P. \& Guerta, C. Q. (2003). Breeding for salinity tolerance in rice. Field Crops Res 76: 91-101.

Gu, X., Y., Zhen, S., L., Yan, X. L. \& Lu, Y., G. (1999). Analysis of generation means for the inheritance of salt tolerance in rice seedling. Acta. Agron. Sin, 25: 686-690.

Guero, Y. (2000). Contibution a l'etude des mecanismes de degradation physico-chimique des sols sous climat sahelien: Example pris dans la valee du moyen Niger. doctorat, Abdou Moumouni de Niamey. 
Hittalmani, S., Foolad, M. R., Mew, T., Rodriguez, R. L. \& Huang, N. (1995). Development of a PCR based marker to identify rice blast resistance gene, pi-2(t), in a segregating population. Theor. Appl. Genet, 91: 9-14.

Hittalmani, S., Huang, N., Courtois, B., Venuprasad, R., Shashidhar, H. E., Zhuang, J. Y., Zheng, K. L., Liu, G. F., Wang, G. C., Sidhu, J. S., Srivantaneeyakul, S., Singh, V. P., Bagali, P. G., Prasanna, H. C., Mclaren, G. \& Khush, G. S. (2003). Identification of QTL for growth- and grain yield-related traits in rice across nine locations of asia. Theor. Appl. Genet, 107: 679-690.

Hu, S., Tao, H., Qian, Q. \& Guo, L. (2012). Genetics and molecular breeding for salt-tolerance in rice Rice Genomics and Genetics, 3: 39-49.

Ikehashi, H. \& Araki, H. (1986). Genetics of f1sterility in remote crosses of rice. In: Rice genetics. IRRI, PO Box 933, Manila, Philippines: 119-130.

IRRI. (2007). Rice breeding methods [Online]. http://www.knowledgebank.irri.org/ericeproduction /0.6_Rice_Breeding.htm [Accessed 2/12 2012].

Ishimaru, K. (2003). Identification of a locus increasing rice yield and physiological analysis of its function. Plant Physiol, 133: 1083-1090.

Izawa, T. (2007). Adaptation of flowering-time by natural and artificial selection in arabidopsis and rice. J Exp Bot, 58: 3091-3097.

Izawa, T., Takahashi, Y. \& Yano, M. (2003). Comparative biology comes into bloom: Genomic and genetic comparison of flowering pathways in rice and arabidopsis. Curr Opin Plant Biol, 6: 113120.

Jacoby, B. (1994). Mechanisms involved in salt tolerance by plants. In: Pessarakli, m. (ed.), handbook of plant and crop stress. Marcel Dekker, New York: 97-123.

Jena, K. K. \& Mackill, D. J. (2008). Molecular markers and their use in marker-assisted selection in rice. crop science, 48: 1266-1276

Jennings, P. R., Coffman, W. R. \& Kauffman, H. E. (1979). Rice improvement. International rice research institute, los baños, Philippines.

Ji, Q., Lu, J., Chao, Q., Gu, M. \& Xu, M. (2005). Delimiting a rice wide compatibility gene s5" to a $50 \mathrm{~kb}$ region. Theor Appl Genet, 111: 1495-1503.

Joseph, B., Jini, D. \& Sujatha, S. (2010). Biological and physiological perspectives of specificity in abiotic salt stress response from various rice plants. Asian Journal of Agricultural Sciences, 2: 99-105

Kamoshita, A., Wade, J., Ali, L., Pathan, S., Zhang, J., Sarkarung, S. \& Nguyen, T. (2002). Mapping qtls for root morphology of a rice population adapted to rain-fed lowland conditions. Theor. Appl. Genet, 104: 880-893.

Khush, G. S. (1978). Breeding methods and procedures employed at IRRI for developing rice germ plasm with multiple resistance to diseases and insects. Pages 69-76 in symposium on methods of crop breeding. Trop. Agric. Res. Ser. 11.

Khush, G. S. (1984). Terminology for rice growing environments. LOS Baños: International Rice Research Institute.

Khush, G. S. (1997). Origin, dispersal, cultivation and variation of rice. Plant Molecular Biology, 35: 25-34.

Kobayashi, S., Araki, E., Osaki, M., Khush, G. S. \& Fukuta, Y. (2006). Localization, validation and characterization of plant-type qtls on chromosomes 4 and 6 in rice (oryza sativa l.). Field Crops Res, 96: 106-112.

Lamond, R. E. \& Whitney, D. A. (1992). Management of saline and sodic soils.Mf-1022. Kansas state University, cooperative extension service, manhattan, kansas. 4pp.

Li, Z. K., Pinson, S. R. M., Stansel, J. W. \& Paterson, A. H. (1998). Genetic dissection of the sourcesink relationship affecting fecundity and yield in rice (oryza sativa l.). Mol Breed, 4: 419-426.

Li, Z. K., Yu, S. B., Lafitte, H. R., Huang, N., Courtois, B., Hittalmani, S., Vijayakumar, C. H., Liu, G. F., Wang, G. C., Shashidhar, H. E., Zhuang, J. Y., Zheng, K. L., Singh, V. P., Sidhu, J. S., Srivantaneeyakul, S. \& Khush, G. S. (2003). QTL x environment interactions in rice. I. Heading date and plant height. Theor. Appl. Genet., 108: 141-153. 
Lin, H. X., Zhu, M. Z., Yano, M., Gao, J. P., Liang, Z. W., Su, W. A., Hu, X. H., Ren, Z. H. \& Chao, D. Y. (2004). Qtls for nat and $\mathrm{k}+$ uptake of the shoots and roots controlling rice salt tolerance. Theoretical and Applied Genetics, 108: 253-260

Linares, O. F. (2002). African rice (oryza glaberrima) history and future potential. proceeding of the national academic science of united state of America, 99: 16360-16365.

Maas, E. V. \& Grattan, S. R. (1999). Crop yields as affected by salinity. Agron Monogr, 38: 55-108.

Maas, E. V. \& Hoffman, G. J. (1977). Crop salt tolerance: Current assessment ASCEJ Irrig Drain Div, 103: 115-134.

Makihara, D., Makoto, T., Miho, M., Yoshihiko, H. \& Toshiro, K. (1999). Effect of salinity on the growth and development of rice (oryza sativa 1.) varieties. Jpn J Trop Agric, 43: 285-294.

Manneh, B., Kiepe, P., Sie, M., Ndjiondjop, M., Drame, N. K., Traore, K., Rodenburg, J., Somado, E. A., Narteh, L., Youm, O., Diagne, A. \& Futakuchi, K. (2007). Exploiting partnerships in research and development to help african rice farmers cope with climate variability SAT eJournal, 4: 24.

Mba, C., Afza, R., Jain, S. M., Gregorio, G. B. \& Zapata-Arias, F. J. (2007). Induced mutations for enhancing salinity tolerance in rice. In: Jenks, M. A. (ed.) Advances in molecular breeding toward drought and salt tolerant crops. Springer.

Ming-Zhe, Y., Jian-Fei, W., Hong-You, C., Hu-Qu, Z. \& Hong-Sheng, Z. (2005). Inheritance and QTL mapping of salt tolerance in rice. Rice Science, 12: 25-32.

Mishra, B. (1994). Breeding for salt tolerance in crops. In: Al, R. E. (ed.) Salinity management for sustainable agriculture: 25 years of research at cssri. Karnal, India: Central Soil Salinity Research Institute.

Mishra, B., Singh, R. K. \& Jetly, V. (1998). Inheritance pattern of salinity tolerance in rice. Journal of Genetics \& Breeding, 52: 325-331.

Moeljopawiro, S. \& Ikehashi, H. (1981). Inheritance of salt resistance in rice. Euphytica, 30: 291-300.

Morishima, H. (1984). Wild plants and domestication in biology of rice. Developments in crop science 7 Tokyo, Japan Scientific Societies Press P 3-30.

Munns, R. (2002). Comparative physiology of salt and water stress. Plant Cell Environ, 25: 239-250.

Munns, R. (2005 ). Genes and salt tolerance: Bringing them together. New Phytol, 167: 645-663.

Munns, R. \& Termaat, A. (1986). Whole-plant responses to salinity. Aust. J. Plant Physiol., 13: 143160.

Munns, R. \& Termaat, A. (1987). Whole-plant responses to salinity. Australian Journal of Plant Physiology, 13: 143-160.

Munns, R. \& Tester, M. (2008). Mechanisms of salinity tolerance. Annual Review of Plant Biology, 59: 651-681.

Nguyen, B. D., Brar, D. S., Bui, B. C., Nguyen, T. V., Pham, L. N. \& Nguyen, H. T. (2002). Identification and mapping of the QTL for aluminum tolerance introgressed from the new source, oryza rufipogon griff., into indica rice (oryza sativa 1.). Theor. Appl. Genet, 106: 583593.

Oldeman, L. R., Hakkeling, R. T. A. \& Sombroek, W. G. (1991). World map of the status of humaninduced soil degradation: An explanatory note, second revised version. Wageningen: International soil and reference center, the netherlands, and nairobi, kenya: International soil reference and information centre/united nations environment programme.

Paterson, A. H. (2012). Genetic architecture of seed dormancy in u.S. Weedy rice in diff erent genetic backgrounds. crop science, 52 2564-2575.

Pearson, K. E. (2004). The basic effects of salinity and sodicity effects on soil physical properties. Information highlight for the general public. http:// waterquality.Montana.edu/docs/methane/ basics_highlight.shtml.

Price, A. H., Townend, J., Jones, M. P., Audebert, A. \& Courtois, B. (2002). Mapping qtls associated with drought avoidance in upland rice grown in the Philippines and west africa. Plant Mol. Biol, 48: 683-695.

Rajendran, K., Tester, M. \& Roy, S. J. (2009). Quantifying the three main components of salinity tolerance in cereals. Plant, Cell and Environment, 32: 237-249. 
Rao, P. S., Mishra, B., Gupta, S. R. \& Rathore, A. (2008). Reproductive stage tolerance to salinity and alkalinity stresses in rice genotypes. Plant Breed, 127: 256-261.

Ren, Z., Gao, J., Li, L., Cai, X., Huang, W., Chao, D., Zhu, M., Wang, Z., Luan, S. \& Lin, H. (2005). A rice quantitative trait locus for salt tolerance encodes a sodium transporter. Nat. Genet, 37: 1141-1146.

Reynolds, M. P., Mujeeb-Kazi, A. \& Sawkins, M. (2005). Prospects for utilising plant-adaptive mechanisms to improve wheat and other crops in drought and salinity prone environments. Ann. Appl. Biol., 146: 239-259.

Richards, R. A. (1984). Should selection for yield in saline regions be made on saline or non-saline soils? . Euphytica, 32: 431-438.

Saito, K., Sokei, Y. \& Wopereis, M. C. S. (2012). Enhancing rice productivity in west africa through genetic improvement. crop science, 52: 484-493.

Sawamura, N. \& Sano, Y. (1996). Chromosomal location of gamete eliminator, s11(t), found in an indica-japonica hybrid. Rice Genet Newsl, 13: 70-71.

Shannon, M. C. (1985). Principles and strategies in breeding for higher salt tolerance. Plant and soil, 89: 227-241.

Shannon, M. C. (1997). Adaptation of plants to salinity. Adv. Agron., 60: 75-120.

Shannon, M. C. \& Grieve, C. M. (1999). Tolerance of vegetable crops to salinity. Scientia Horticulturae, 78: 5-38.

Shannon, M. C., Grieve, C. M. \& Francois, L. E. (1994). Whole-plant response to salinity. In: Wilkinson, R. E. (ed.) Plant-environment interactions. New York: Marcel Dekker.

Shen, B., Zhuang, J. Y., Zhang, K. Q., Xia, Q. Q., Sheng, C. X. \& Zheng, K. L. (2003). Qtls mapping of leaf traits and root vitality in a recombinant inbred line population of rice. Acta Genet Sin, 30: 1133-1139.

Shibaya, T., Nonoue, Y., Ono, N., Yamanouchi, U., Hori, K. \& Yano, M. (2011). Genetic interactions involved in the inhibition of heading by heading date QTL, hd2 in rice under long-day conditions. Theor Appl Genet: DOI 10.1007/s00122-011-1654-0.

Sido, A. Y. (2010). Etat de lieu de la riziculture: Cas du Niger. Niamey: FAO.

Simmonds, N. W. (1991). Selection for local adaptation in a plant breeding programme. Theoretical and Applied Genetics, 82: 363-367.

Singh, R. K., Adorada, D. L., Magsino, C., Roque, Z., Tamayo, N. \& Gregorio, G. B. (2005). Temperature and relative humidity affect salinity tolerance in rice, page 1-2. 10th international congress of sabrao, Tsukuba, Japan, 22-23 august. Abstract proceeding.

Singh, R. K. \& Mishra, B. (1995). Screening f1 anther culture derivatives of rice for salt tolerance. In: Sharma, B. (ed.) Genetic research and education: Current trends and the next fifty years. . New Delhi: Indian Society of Genetics and Plant Breeding. Ind J Genet Plant Breed

Singh, R. K., Mishra, B. \& Jetly, V. (2001). Segregations for alkalinity tolerance in three rice crosses. SABRAO J, 33: 31-34.

Singh, R. K., Mishra, B. \& Senadhira, D. (1992). Promising salt tolerant f1 anther culture derivatives (acds). Int rice res newsl 17:17.

Singh, R. K., Redoña, E. \& Luzminda Refuerzo, L. (2010a). Varietal improvement for abiotic stress tolerance in crop plants. In: Bohnert, H. J. (ed.) Abiotic stress adaptation in plants. IRRI.

Singh, R. K., Redoña, E. \& Refuerzo, L. (2010b). Varietal improvement for abiotic stress tolerance in crop plants: Special reference to salinity in rice. In: Pareek, A., Sopory, S. K. \& Bohnert, H. J. (eds.) Abiotic stress adaptation in plants: Physiological, molecular and genomic foundation.

Song, W. Y., Wang, G. L., Chen, L. L., Kim, H. S., Pi, L. Y., Holsten, T., Gardner, J., Wang, B., Zhai, W. X., Zhu, L. H., Fauquet, C. \& Ronald, P. (1995). A receptor kinase-like protein encoded by the rice disease resistance gene, xa21. Science, 270: 1804-1806.

Srivastava, J. P. \& Jana, S. (1984). Screening wheat and barley germplasm for salt tolerance. In: Staples, R. C. \& Toenniessen, G. H. (eds.) Salinity tolerance in plants strategies for crop improvement New York, NY: Wiley. 
Subudhi, P. K., Sasaki, T. \& Khush, G. S. (2006). Rice. Genome mapping and molecular breeding of plant in plant cereals and millets. Verlag Berlin Heidelberg.

Sun, X., Cao, Y., Yang, Z., Xu, C., Li, X., Wang, S. \& Zhang, Q. (2004). Xa26, a gene conferring resistance to xanthomonas oryzae pv. Oryzae in rice, encodes an lrr receptor kinase-like protein. Plant J., 37: 517-527.

Takehisa, H., Shimoda, Y., Fukuta, Y., Ueda, T., Yano, M., Yamaya, T., Kameya, T. \& Sato, T. (2004). Identification of quantitative trait loci for plant growth of rice in paddy field flooded with salt water. Field Crops Res, 89: 85-95.

Thi Lang, N., Thi Luy, T., Chi Buu \& Albel Ismail, A. (2010). The genetic association between the yield, yield component and salt tolerance in rice. Omonrice, 17: 99-104.

Thomson, M. J., Tai, T. H., Mcclung, A. M., Lai, X. H., Hinga, M. E., Lobos, K. B., Xu, Y., Martinez, C. P. \& Mccouch, S. R. (2003). Mapping quantitative trait loci for yield, yield components and morphological traits in an advanced backcross population between oryza rufipogon and the oryza sativa cultivar jefferson Theor Appl Genet, 107: 479-493.

Tong, H. H., Mei, H. W., Xing, Y. Z., Cao, Y. P., Yu, X. Q., Zhang, S. Q. \& Luo, L. J. (2007). QTL analysis for morphological and physiological characteristics of flag leaf at the late developmental stage in rice. Chinese J Rice Sci, 21: 493-499.

Toriyama, K., Heong, K. L. \& Hardy, B. (eds.) (2005). Rice is life: Scientific perspectives for the 21st century. Proceedings of the world rice research conference held in tokyo and Tsukuba, Japan, 47 November 2004., Los Baños (Philippines): International Rice Research Institute, and Tsukuba (Japan): Japan International Research Center for Agricultural Sciences. CD-ROM. 590 p.

Valent, B., Bryan, G. T., Jia, Y., Farrall, L., Mcadams, S. A., Faulk, K. N. \& Levy, M. (2001). Enhancing deployment of rice blast resistance genes: Opportunities from cloning a resistance gene/avirulence gene pair. In: Khush, G. J., Brar, D. S. \& Hardy, B. (eds.) Rice genetics iv. NH, USA: Science Publishers.

Van De Graaff, R. \& Patterson, R. (2001). Explaining the mysteries of salinity, sar and esp in on-site practice. http://www.launionsweb.org/salinity.htm.

Vaughan, D. A. (1994). The wild relatives of rice. A genetic handbook. international rice Research Institute, Manila.

Wan, J., Ikehashi, H., Sakai, M., Horisue, H. \& Imbe, T. (1998). Mapping of hybrid sterility genes s17 of rice (oryza sativa 1.) by isozyme and rflp markers. Rice Genet Newsl, 15: 151-154.

Wang, J., Liu, K., Xu, C., Li, X. \& Zhang, Q. (1998). The high level of wide compatibility of variety 'dular' has a complex genetic basis. Theor Appl Genet, 97: 407-412.

Xie, J. H., Zapata, A. F. J., Shen, M. \& Afza, R. (2001). Salinity tolerant performance and genetic diversity of four rice varieties. Euphytica, 116: 105-110.

Yan, C., Liang, G., Zhu, L. \& Gu, M. (2000). Rflp analysis on wide compatibility genes in rice variety 'dular' of ecotype aus (in chinese). Acta Genet Sin, 27: 409-417.

Yoon, D. B., Kang, K. H., Kim, H. J., Ju, H. G., Kwon, S. J., Suh, J. P., Jeong, O. Y. \& Ahn, S. N. (2006). Mapping quantitative trait loci for yield components and morphological traits in an advanced backcross population between oryza grandiglumis and the o. Sativa japonica cultivar hwaseongbyeo. Theor Appl Genet, 112: 1052-1062.

Yoshimura, S., Yamanouchi, U., Katayose, Y., Toki, S., Wang, Z. X., Kono, I., Kurata, N., Yano, M., Iwata, N. \& Sasaki, T. (1998). Expression of xa1, a bacterial blight-resistance in rice, is induced by bacterial inoculation. Proc. Nat. Acad. Sci. USA, 95: 1663-1668.

Yue, B., Xue, W. Y., Luo, L. J. \& Xing, Y. Z. (2006). QTL analysis for flag leaf characteristics and their relationships with yield and yield traits in rice. Acta Genet Sin, 33: 824-832.

Zeng, L. \& Shannon, M. C. (2000). Effects of salinity on grain yield and yield components of rice at different seeding densities. agron. J., 92: 418-423.

Zhang, G. \& Lu, Y. (1996). Genetics of f1pollen sterility in oryza sativa. In: Khush gs (ed) rice genetics iii. IRRI, Manila, Philippines: 418-422.

Zhang, H., Zhang, C., Sun, Z., Yu, W., Gu, M., Liu, Q. \& Li, Y. (2011). A major locus qs12, located in a duplicated segment of chromosome 12, causes spikelet sterility in an indica-japonica rice hybrid. Theor Appl Genet, 123: 1247-1256. 
Zhao, Z. G., Wang, C. M., Jiang, L., Zhu, S. S., Ikehashi, H. \& Wan, J. M. (2006). Identification of a new hybrid sterility gene in rice (oryza sativa l.). Euphytica, 151: 331-337.

Zheng, H. G., Babu, R. C., Pathan, M. S., Ali, L., Huang, N., Courtois, B. \& Nguyen, H. T. (2000). Quantitative trait loci for root-penetration ability and root thickness in rice: Comparison of genetic backgrounds. Genome, 43: 53-61.

Citation: O. Souleymane et al., " Genetic Improvement of Rice (Oryza sativa) For Salt Tolerance: A Review ", International Journal of Advanced Research in Botany, vol. 3, no. 3, p. 12, 2017. http://dx.doi.org/10.20431/2455-4316.0303004

Copyright: (c) 2017 Authors. This is an open-access article distributed under the terms of the Creative Commons Attribution License, which permits unrestricted use, distribution, and reproduction in any medium, provided the original author and source are credited. 